\title{
Physicochemical evaluation of oil blends of Glycine max L., Helianthus annus L. and Cocos nucifera L. under thermoxidation
}

\author{
Andressa Alves Pinheiroa®, Neuza Jorge $\mathrm{a}^{*} \bullet$ \\ a Programa de Pós-Graduação em Engenharia e Ciência de Alimentos, Universidade Estadual Paulista "Júlio de Mesquita Filho", São \\ José do Rio Preto, 15054-000, São Paulo,Brasil.*neuza.jorge@unesp.br
}

Received: February 2, 2021 / Accepted: May 05, 2021/ Published online: May 27, 2021

\begin{abstract}
The predominance of mono and polyunsaturated fatty acid of Glycine max L. (soybean) and Helianthus annus L. (sunflower) oils make them more unstable under high temperatures and susceptible to oxidation. On the other hand, the composition of the Cocos nucifera $\mathrm{L}$. (coconut) oil is predominantly saturated and has high oxidative stability. The formulation of oil blends allows some improvements in their nutritional and physicochemical characteristics. Thus, the aim of this work is to evaluate the $G$. max oil (SB), H. annus oil (SF), C. nucifera oil (C) and the blends G. max:C. nucifera (SB:C, 75:25 v/v) and H. annus:C. nucifera (SF:C, 75:25 v/v) as to their physicochemical properties when under thermoxidation $\left(180{ }^{\circ} \mathrm{C} / 15 \mathrm{~h}\right)$. Before the thermoxidation, the $\mathrm{C}$ presented less degradation in relation to the others, while the $\mathrm{SF}: \mathrm{C}$ was the most efficient in inhibiting oxidation due to the presence of low levels of peroxide values, however, it presented less degradation to $\rho$-anisidine and conjugated dieneic acids. The SF:C presented higher oxidative stability and less degradation in relation to SB:C. Consequently, the application of these oil blends is recommendable in processes that involve high temperatures, such as frying.
\end{abstract}

Keywords: Fatty acids, high temperaturas, oxidation, vegetable oils.

\section{Avaliação físico-química de misturas de óleos de Glycine max L., Helianthus annus L. e Cocos nucifera L. sob termoxidação}

\begin{abstract}
Resumo
O predomínio de ácidos graxos mono e poli-insaturados nos óleos de Glycine max L. (soja) e Helianthus annus L. (girassol) os tornam mais instáveis sob elevadas temperaturas e suscetíveis à oxidação. Por outro lado, a composição do óleo de Cocos nucifera L. (coco) é predominantemente saturada e possui alta estabilidade oxidativa. A formulação de misturas de óleos permite algumas melhorias em suas características físico-químicas e nutricionais. Assim, o objetivo deste trabalho é avaliar os óleos de G. max (SB), H. annus (SF), C. nucifera (C) e as misturas G. max: $C$. nucifera (SB:C, 75:25 v/v) e H. annus: $C$. nucifera (SF:C, 75:25 v/v) quanto às suas propriedades físico-químicas quando submetidos à termoxidação $\left(180{ }^{\circ} \mathrm{C} / 15 \mathrm{~h}\right)$. Antes da termoxidação, o C apresentava menor degradação em relação aos demais, enquanto o SF:C foi o mais eficiente em inibir a oxidação devido à presença de baixos teores de peróxidos, porém apresentou menor degradação para $\rho$-anisidina e ácidos dienóicos conjugados. O SF:C apresentou maior estabilidade oxidativa e menor degradação em relação ao SB:C. Consequentemente, a aplicação dessas misturas de óleos é recomendável em processos que envolvam altas temperaturas, como fritura.
\end{abstract}

Palavras-chave: Ácidos graxos, altas temperaturas, óleos vegetais, oxidação.

\section{Introduction}

The lipidic oxidation causes the deterioration of the physiological mechanisms of raw materials, which can appear during its heating or long-term storage. The main mechanism of oil and fat oxidation is the self-oxidation. This reaction is spontaneous and it happens between atmospheric oxygen and lipids causing the oxidative deterioration (Weng \& Wang, 2000).

The minority components of food, such as the vitamins and the essential fatty acids, can decompose developing flavors and unpleasant odors, besides forming compounds that are toxic to health (Silva, Borges, \& Ferreira, 1999). Vegetable oils with high content of polyunsaturated fatty acids have high potential for self-oxidation. The relation between oleic fatty acids and linoleic is important to determine the shelf life of the oil.

The higher amount of polyunsaturated in relation to monounsaturated, the shorter its lifespan will be and the higher its oxidation (Nyam, Tan, Lai, Long, \& Che Man, 2009). 
Vegetable oils are fundamental for a good functioning of the human body (Savva \& Kafatos, 2016). The fatty acid composition differs each kind of oil. Under the nutritional point of view, the best proportion to be daily consumed for the maintenance of a balanced diet is of approximately 1:1:1 of saturated, monounsaturated and polyunsaturated fatty acids (ICMR, 1989; LaRosa et al., 1990). The G. max, H. annus and $C$. nucifera oils are produced in large scale worldwide. The $G$. max is mostly polyunsaturated and its main constituent is the linoleic $(\omega 6)$. This fatty acid is capable of having an antiinflammatory effect, besides preventing cancer (Miles \& Calder, 2012; Sawada, 2012). On the other side, it has low oxidative stability in high temperature processes.

The mid-oleic $H$. annus oil, mostly monounsaturated, mainly oleic fatty acid (Codex Alimentarius, 2009). The reduction of occurrences of heart diseases are related to the consumption of oleic, however, in high temperatures, it is not very stable (Mahan \& Escott-Stump, 2010).

The $C$. nucifera oil contains medium chain fatty acids, mainly lauric acid (Patil \& Benjakul, 2019) and when ingested it is transported to the liver and converted in energy, being easily digested (Dayrit, 2015; Ribeiro, 2017). The composition of more than $90 \%$ of saturated fatty acids is responsible for granting the oil oxidative stability. In reason of several health benefits and high stability, gained interest in the consumer and industry (Patil \& Benjakul, 2018).

Each oil has its physical-chemical singularity, the combination of two or more kinds of oils is necessary to allow improvements. Some of the changes are new nutritional characteristics, fatty acids diversity, physical-chemical property modification and oxidative stability increase.

Oils and fats change easily when stored, degrade and can form toxic compounds, therefore, it is necessary to analyze them and check if they are suitable for use. The most used parameters for measuring lipid oxidation are: analysis of free fatty acids, peroxides, $\rho$-anisidine, total oxidation value (Totox), conjugated dienoic acids, polar compounds and oxidative stability, among others.

Therefore, the study aims at characterizing the physicochemical properties and the profile of the fatty acids of the G. max, H. annus, C. nucifera and their blends, G. max: $C$. nucifera and $H$. annus: $C$. nucifera. Moreover, analyzing the behavior of these oils under thermoxidation conditions at 180 $\pm 5^{\circ} \mathrm{C}$ during periods of $0,5,10,15 \mathrm{~h}$.

\section{Materials e Methods}

\section{Raw materials}

The extra virgin, cold pressed refined oils of $G$. $\max (\mathrm{SB})$, midoleic $H$. annus (SF) and $C$. nucifera $(\mathrm{C})$ were bought in a local store (São José do Rio Preto, São Paulo, Brazil).

The formulation of the oil blends, G. max:C. nucifera (SB:C) and $H$. annus:C. nucifera $(\mathrm{SF}: \mathrm{C})$, was defined after a preliminary test whose objective was to obtain the approximated proportion of 1:1:1 of saturated, monounsaturated and polyunsaturated fatty acids, respectively. The oils SB, SF and C were use in the proportion of 100 , however SB:C and SF:C 75:25, v/v.

\section{Thermoxidation}

The thermoxidation of the oils was made under a discontinuous way, that is, $10 \mathrm{~h}$ of heating on the first day and $5 \mathrm{~h}$ on the following day. The oils were thermoxidized on a heated plate at $180 \pm 5^{\circ} \mathrm{C}$ with surface/volume ratio of $0.4 / \mathrm{cm}$. Samples were collected at $0,5,10$ and $15 \mathrm{~h}$ of heating and afterwards, cooled down in room temperature, stored in amber glass pots and inertized with gaseous nitrogen. The samples were stowed at a temperature of -18 ${ }^{\circ} \mathrm{C}$ until the moment of the analyses.

\section{Physicochemical analysis}

Free fatty acids (FFAs), expressed in \% of oleic, were determined according to the norm Ca $5 \mathrm{a}-40$ of AOCS (2009). The acidity value (AV), in $\mathrm{mg} \mathrm{NaOH} / \mathrm{g}$, was calculated by multiplying FFAs by 1.99 . The peroxide values (PV) and $\rho$ anisidine $(\rho \mathrm{AV})$ were measured according to the methods $\mathrm{Cd}$ 8-53, expressed in meq $\mathrm{O}_{2} / \mathrm{kg}$ and $\mathrm{Cd} 18-90$ of AOCS (2009), respectively. The total oxidation value (Totox) was calculated according to Huimin et al. (2014) by the following formula: Totox $=2 \mathrm{PV}+\rho \mathrm{AV}$.

The conjugated dienoic acids (CDA), expressed in \%, were measured by the method Ti 1a-64 of AOCS (2009). To determine the total polar compounds, expressed in \%, the chromatographic method was used in columns according to Dobarganes, Velasco and Dieffenbacher (2000). The refractive index, iodine and saponification values were evaluated according to the $\mathrm{Cc} 7-25, \mathrm{Cd} 1 \mathrm{c}-85$ e $\mathrm{Cd} 3 \mathrm{a}-94$ methods of AOCS (2009) and expressed in $40{ }^{\circ} \mathrm{C}, \mathrm{g} \mathrm{I}_{2} / 100 \mathrm{~g}$ and $\mathrm{mg} \mathrm{KOH} / \mathrm{g}$, respectively.

The oxidative stability index (OSI) was determined following the Cd 12b-92 of AOCS (2009) method, using the Rancimat equipment (743 model, Metrohm Ltd, Herisau, Switzerland). For this determination, $3 \mathrm{~g}$ of oil and airflow at $20 \mathrm{~L} / \mathrm{h}$ at temperature of $110^{\circ} \mathrm{C}$ were used. The induction period was expressed in $h$.

The fatty acid methyl esters composition was determined according to the Ce 1-62 method of AOCS (2009) by capillary gas chromatography-CGC, using an Agilent 6850 Series GC System equipped with a $60 \mathrm{~m}$ Agilent DB-23 capillary column (50\% cyanopropyl-methylpolysiloxane), internal diameter of $0.25 \mathrm{~mm}$ and $0.25 \mu \mathrm{m}$ film. The conditions for the chromatographic operations were as follows: column flow $=1.0 \mathrm{~mL} / \mathrm{min}$; linear velocity $24 \mathrm{~cm} / \mathrm{s}$; detector temperature $280{ }^{\circ} \mathrm{C}$; injector temperature $250{ }^{\circ} \mathrm{C}$; oven temperature at $110^{\circ} \mathrm{C}$ for $5 \mathrm{~min}$, then rising from 110 to $215^{\circ} \mathrm{C}$ at $5^{\circ} \mathrm{C} / \mathrm{min}$, followed by $215^{\circ} \mathrm{C}$ for $34 \mathrm{~min}$; carrier gas of helium; volume injected $1.0 \mu \mathrm{L} ; 1: 50$ split. The fatty acid methyl esters were prepared by adapting the method described by Hartman and Lago (1973) to a micro-scale.

\section{Reagents}

The reagents used in this study were obtained by commercial source: ethylic alcohol 95\%, sodium hydroxide $0,1 \mathrm{M}$, phenolphthalein, acetic acid, chloroform, potassium iodide, sodium thiosulfate $0.01 \mathrm{M}$, starch, $\rho$-anisidine, isooctane, hexane, ethyl ether, silica gel (granulometry 0.0630.200 mm, n. 7734, Sigma-Aldrich, Merck, Bellefonte, PA), 
sea sand, iodine, potassium hydroxide, cyanopropyl methylpolisyloxane, gaseous nitrogen.

\section{Statistical analysis}

The results obtained from the analytical determinations, in triplicate, were subjected to variance analysis and the differences between means were tested at $5 \%$ probability by the Tukey test. The software used was the ESTAT 2.0 version (UNESP, Jaboticabal, São Paulo, Brasil).

\section{Results and Discussion}

The physicochemical analyses for the characterization of the oils are presented on Table 1 . The free fatty acids content and acidity index of oils and fats are related to the occurrence of hydrolysis in the oil and, consequently, its final quality (Farhoosh et al., 2009). According to Codex Alimentarium (2009), the recommended acidity index for refined and crude oils cold pressed is of 0.6 and $4 \mathrm{mg} \mathrm{KOH} / \mathrm{g}$, respectively.

Table 1. Characterization of the G. max, H. annus, C. nucifera oils and their blends.

\begin{tabular}{|c|c|c|c|c|c|}
\hline Analyses & SB & SF & $\mathrm{C}$ & SB:C & $\mathrm{SF}: \mathrm{C}$ \\
\hline FFAs (\%) & $0.13 \pm 0.01^{b}$ & $0.13 \pm 0.01^{b}$ & $0.19 \pm 0.01^{\mathrm{a}}$ & $0.14 \pm 0.00^{b}$ & $0.14 \pm 0.00^{\mathrm{b}}$ \\
\hline $\mathrm{AV}(\mathrm{mg} \mathrm{KOH} / \mathrm{g})$ & $0.26 \pm 0.01^{\mathrm{b}}$ & $0.26 \pm 0.01^{b}$ & $0.38 \pm 0.01^{\mathrm{a}}$ & $0.28 \pm 0.00^{\mathrm{b}}$ & $0.28 \pm 0.00^{\mathrm{b}}$ \\
\hline $\mathrm{RI}\left(40^{\circ} \mathrm{C}\right)$ & $.468 \pm 0.001^{\mathrm{a}}$ & $1.467 \pm 0.001^{\mathrm{a}}$ & $1.446 \pm 0.000^{\mathrm{b}}$ & $1.463 \pm 0.001^{\mathrm{a}}$ & $1.462 \pm 0.000^{\mathrm{a}}$ \\
\hline $\mathrm{IV}\left(\mathrm{g} \mathrm{I}_{2} / 100 \mathrm{~g}\right)$ & $23.81 \pm 0.00^{\mathrm{a}}$ & $111.87 \pm 0.00^{\mathrm{b}}$ & $8.68 \pm 0.00^{\mathrm{e}}$ & $97.66 \pm 0.00^{c}$ & $86.79 \pm 0.00^{\mathrm{d}}$ \\
\hline $\mathrm{SV}(\mathrm{mg} \mathrm{KOH} / \mathrm{g})$ & $00.86 \pm 0.00^{\mathrm{d}}$ & $197.01 \pm 0.00^{\mathrm{e}}$ & $264.84 \pm 0.04^{\mathrm{a}}$ & $217.99 \pm 0.05^{\mathrm{b}}$ & $213.05 \pm 0.03^{\mathrm{c}}$ \\
\hline
\end{tabular}

The oils analyzed agree with the stipulated limits and the highest result found for the free fatty acids content and acidity index is the $C$. nucifera oil since it is a crude oil which did not go through refining processes. The oils SB, SF, SB:C and SF:C did not differ statistically, showing the lowest averages.

Khan, Asha, Bhat and Khatoon (2011) found the values of $0.9 ; 1.6$ and $0.5 \%$ of free fatty acids, in oleic, for oil blends of virgin $C$. nucifera:S. indicum $(1: 1, \mathrm{v} / \mathrm{v})$, refined $C$. nucifera: $S$. indicum $(1: 1, \mathrm{v} / \mathrm{v})$ and refined $C$. nucifera:E. guineensis oil $(1: 1, \mathrm{v} / \mathrm{v})$, respectively. On the other hand, Marina, Che-Man, Nazimah and Amin (2009) found for the virgin C. nucifera oil of different brands from 0.15 to $0.25 \%$ in oleic.

Refractive index and iodine value are measures that analyze the level of instauration of the oils. According to Gunstone (2011), the lower the refractive index, the lower the amount of unsaturation and, consequently, the more stable the oil will be. As reported by The Codex Alimentarius (2009), the established levels for the refractive index of the oils $\mathrm{SB}, \mathrm{SF}$, and $\mathrm{C}$ are 1.466-1.467; $1.461-1.468$ and $1.448-1.450$, respectively. The $\mathrm{SB}, \mathrm{SF}$ and $\mathrm{C}$ studied oils agree with the established limits for the refractive index and the SB:C and SF:C blends present intermediary levels compared to the pure oils.

In relation to the iodine value, the $G$. max oil presented the highest amount of unsaturation due to its composition of linoleic acid predominantly. Meanwhile, the $C$. nucifera oil presented the lowest index because it is mostly saturated.

The $C$. nucifera oil presented the highest saponification value, approximately $265 \mathrm{mg} \mathrm{KOH} / \mathrm{g}$, since it is mostly constituted by fatty acids of low molecular weight. On the other side, the SB:C and SF:C presented approximated values of $215 \mathrm{mg} \mathrm{KOH} / \mathrm{g}$, because the highest amounts of fatty acids are monounsaturated and polyunsaturated. According to Toscano, Riva, Foppa-Pedretti and Duca (2012), the refined $G$. max and $H$. annus oils present saponification values of 190.1 and $193.5 \mathrm{mg} \mathrm{KOH} / \mathrm{g}$, respectively.

The Table 2 refers to the profile of the fatty acids of the studied oils. The G. max, the $H$. annus and the $C$. nucifera oils are mostly constituted by polyunsaturated fatty acids (linoleic), monounsaturated (oleic) and saturated (lauric), respectively.
The G. max and H. annus oils are rich in $\omega 6$, essential fatty acid, which is efficient in fighting diseases, such as cancer (Sawada, 2012), anti-inflammatory processes and migraine (Santos \& Weaver, 2018). The G. max oil has approximately $50 \%$ of $\omega 6$, while the $H$. annus oil has $47 \%$ of oleic. On the other hand, the C. nucifera oil has $47 \%$ of lauric.

The varied fatty acid composition, monounsaturated and polyunsaturated, of the $G$. $\max$ and $H$. annus oils contribute aggregating more diversity to the $C$. nucifera oil profile. Therefore, the oil blends are more complete, have more variety and more balanced amount of fatty acids when compared to their pure oils (Boukandoul et al., 2019).

The SB:C oil is mostly constituted by polyunsaturated fatty acids (45\%). The balance in the composition of these acids is showed in the relation saturated:monounsaturated:polyunsaturated (sat:mono:poly) in which the studied oil presented the proportion 1:1.6:2.2. Another important relation is the one related to the oleic and linoleic (ole/lin) composition which found value is 1/1.19.

According to Nyam et al. (2009), the relation between the content of ole/lin fatty acid determines the oil shelf life. Thus, the higher the amount of polyunsaturated in relation to monounsaturated, the higher the oxidation.

The SF:C oil, rich in monounsaturated fatty acids (37\%) is the second more thermally stable when compared to the others. The relation oleic and linoleic is $1 / 0.83$ and the proportion sat:mono:poly is $1: 1.2: 1.1$. The $\mathrm{SF}: \mathrm{C}$ is the only oil that approximated the established proportions (ICMR, 1989; LaRosa et al., 1990).

According to Table 3 , initially in relation to the peroxide value, the analyzed oils agreed with the maximum stipulated limit - refined and virgin oils or cold pressed is 10 and 15 $\mathrm{meq} / \mathrm{kg}$, respectively. The lowest levels refer to the SB and $\mathrm{C}$ oils which did not differ statistically.

During thermoxidation, the $C$. nucifera oil presented variations as to the peroxide value, possibly as a consequence of its production process, since it does not go through the traditional refinement steps (neutralization, clarification and deodorization). The formation of 
hydrocarbons, hydroperoxides, free radicals and volatile compounds also contribute to the increase of the oil oxidation.

At the end of the $15 \mathrm{~h}$, the SB and SF oils increased their peroxide values without oscillation. On the other hand, SB:C and SF:C presented the lowest values, although during thermoxidation they presented oscillation due to the significative presence of $\mathrm{C}$.
Khan et al. (2011) obtained 6.2; 5.4 and $0.6 \mathrm{meq} / \mathrm{kg}$ for the peroxide values on the three kinds of oil blends: virgin $C$. nucifera: $S$. indicum $(1: 1, \mathrm{v} / \mathrm{v})$, refined $C$. nucifera:S. indicum $(1: 1, \mathrm{v} / \mathrm{v})$ and refined $C$. nucifera: E. guineensis oil $(1: 1, \mathrm{v} / \mathrm{v})$, respectively, in $15 \mathrm{~h}$ of frying at $175^{\circ} \mathrm{C}$ and $\mathrm{S} / \mathrm{V}$ of $0.3 / \mathrm{cm}$.

Table 2. Profile of the fatty acids of the G. max, H. annus, C. nucifera oils and their blends.

\begin{tabular}{|c|c|c|c|c|c|}
\hline Fatty acids $(\%)$ & SB & SF & $\mathrm{C}$ & SB:C & SF:C \\
\hline \multicolumn{6}{|c|}{ Saturated } \\
\hline Caproic & nd & nd & 0.24 & nd & nd \\
\hline Caprylic & nd & nd & $7.73 \pm 0.01^{\mathrm{a}}$ & $1.80 \pm 0.02^{\mathrm{b}}$ & $1.84 \pm 0.02^{b}$ \\
\hline Capric & nd & nd & $6.31 \pm 0.02^{\mathrm{a}}$ & $1.49 \pm 0.02^{\mathrm{b}}$ & $1.53 \pm 0.01^{\mathrm{b}}$ \\
\hline Lauric & $0.21 \pm 0.02^{\mathrm{d}}$ & $0.10 \pm 0.01^{\mathrm{d}}$ & $47.63 \pm 0.07^{a}$ & $11.38 \pm 0.02^{\mathrm{c}}$ & $11.53 \pm 0.03^{b}$ \\
\hline Myristic & $0.21 \pm 0.01^{\mathrm{c}}$ & $0.13 \pm 0.02^{c}$ & $17.60 \pm 0.03^{\mathrm{a}}$ & $4.33 \pm 0.06^{\mathrm{b}}$ & $4.33 \pm 0.10^{\mathrm{b}}$ \\
\hline Pentadecanoic & $0.02 \pm 0.01^{\mathrm{a}}$ & $0.03 \pm 0.01^{\mathrm{a}}$ & $0.02 \pm 0.01^{\mathrm{a}}$ & $0.03 \pm 0.01^{\mathrm{a}}$ & $0.02 \pm 0.01^{\mathrm{a}}$ \\
\hline Palmitc & $11.21 \pm 0.01^{\mathrm{a}}$ & $5.47 \pm 0.16^{\mathrm{e}}$ & $8.60 \pm 0.04^{c}$ & $10.37 \pm 0.05^{\mathrm{b}}$ & $6.52 \pm 0.02^{\mathrm{d}}$ \\
\hline Margaric & $0.10 \pm 0.01^{\mathrm{a}}$ & $0.06 \pm 0.01^{\mathrm{a}}$ & $0.02 \pm 0.01^{\mathrm{a}}$ & $0.08 \pm 0.02^{\mathrm{a}}$ & $0.04 \pm 0.01^{\mathrm{a}}$ \\
\hline Stearic & $3.81 \pm 0.03^{\mathrm{a}}$ & $3.31 \pm 0.04^{\mathrm{d}}$ & $3.41 \pm 0.03^{\mathrm{cd}}$ & $3.59 \pm 0.09^{b}$ & $3.44 \pm 0.02^{\mathrm{c}}$ \\
\hline Arachidic & $0.37 \pm 0.02^{\mathrm{a}}$ & $0.28 \pm 0.03^{\mathrm{ab}}$ & $0.12 \pm 0.02^{c}$ & $0.31 \pm 0.01^{\mathrm{ab}}$ & $0.24 \pm 0.02^{\mathrm{bc}}$ \\
\hline Behenic & $0.49 \pm 0.02^{b c}$ & $0.79 \pm 0.02^{\mathrm{a}}$ & $0.04 \pm 0.02^{\mathrm{d}}$ & $0.38 \pm 0.02^{c}$ & $0.60 \pm 0.02^{\mathrm{b}}$ \\
\hline Lignoceric & $0.18 \pm 0.01^{\mathrm{ab}}$ & $0.27 \pm 0.02^{\mathrm{a}}$ & $0.04 \pm 0.01^{\mathrm{c}}$ & $0.15 \pm 0.02^{\mathrm{bc}}$ & $0.21 \pm 0.01^{\mathrm{ab}}$ \\
\hline Total & $16.60 \pm 0.10^{\mathrm{d}}$ & $10.44 \pm 0.03^{\mathrm{e}}$ & $91.76 \pm 0.20^{\mathrm{a}}$ & $33.91 \pm 0.08^{b}$ & $30.31 \pm 0.05^{\mathrm{c}}$ \\
\hline \multicolumn{6}{|c|}{ Monounsaturated } \\
\hline Palmitoleic & $0.13 \pm 0.01^{\mathrm{a}}$ & $0.11 \pm 0.01^{\mathrm{a}}$ & $0.05 \pm 0.01^{\mathrm{a}}$ & $0.09 \pm 0.02^{\mathrm{a}}$ & $0.11 \pm 0.01^{\mathrm{a}}$ \\
\hline Cis-10-heptadecenoic & $0.06 \pm 0.01^{\mathrm{a}}$ & $0.05 \pm 0.01^{\mathrm{a}}$ & nd & $0.04 \pm 0.01^{\mathrm{a}}$ & $0.04 \pm 0.01^{\mathrm{a}}$ \\
\hline Oleic & $24.96 \pm 0.05^{\mathrm{c}}$ & $47.55 \pm 0.17^{\mathrm{a}}$ & $6.29 \pm 0.03^{\mathrm{e}}$ & $20.33 \pm 0.03^{\mathrm{d}}$ & $37.36 \pm 0.02^{b}$ \\
\hline Eicosanoic & $0.27 \pm 0.01^{\mathrm{a}}$ & $0.23 \pm 0.01^{\mathrm{a}}$ & $0.05 \pm 0.01^{\mathrm{b}}$ & $0.18 \pm 0.01^{\mathrm{a}}$ & $0.19 \pm 0.01^{\mathrm{a}}$ \\
\hline Total & $25.42 \pm 0.02^{c}$ & $47.94 \pm 0.02^{\mathrm{a}}$ & $6.39 \pm 0.07^{\mathrm{e}}$ & $20.64 \pm 0.05^{\mathrm{d}}$ & $37.70 \pm 0.03^{\mathrm{b}}$ \\
\hline \multicolumn{6}{|c|}{ Polyunsaturated } \\
\hline t-Linoleic & $0.57 \pm 0.01^{\mathrm{a}}$ & $0.55 \pm 0.03^{\mathrm{a}}$ & $0.08 \pm 0.02^{c}$ & $0.46 \pm 0.02^{\mathrm{ab}}$ & $0.43 \pm 0.01^{\mathrm{b}}$ \\
\hline Linoleic & $50.50 \pm 0.10^{\mathrm{a}}$ & $40.36 \pm 0.04^{b}$ & $1.67 \pm 0.03^{\mathrm{e}}$ & $39.62 \pm 0.12^{c}$ & $30.93 \pm 0.03^{\mathrm{d}}$ \\
\hline t-Linolenic & $1.36 \pm 0.01^{\mathrm{a}}$ & $0.41 \pm 0.01^{\mathrm{c}}$ & nd & $1.04 \pm 0.01^{\mathrm{b}}$ & $0.31 \pm 0.01^{\mathrm{c}}$ \\
\hline$\alpha$-Linolenic & $5.56 \pm 0.02^{\mathrm{a}}$ & $0.30 \pm 0.02^{c}$ & $0.11 \pm 0.01^{\mathrm{d}}$ & $4.33 \pm 0.03^{\mathrm{b}}$ & $0.32 \pm 0.01^{\mathrm{c}}$ \\
\hline Total & $57.99 \pm 0.02^{\mathrm{a}}$ & $41,62 \pm 0.22^{\mathrm{c}}$ & $1.86 \pm 0.02^{\mathrm{e}}$ & $45.45 \pm 0.07^{b}$ & $31.99 \pm 0.04^{\mathrm{d}}$ \\
\hline Sat:Mono:Poly & $1: 1.5: 3.5$ & $1: 4.6: 4.0$ & $1: 4.6: 4.0$ & $1: 1.6: 2.2$ & $1: 1.2: 1.1$ \\
\hline Ole/Lin & $1 / 2.02$ & $1 / 0.85$ & $1 / 0.27$ & $1 / 1.95$ & $1 / 0.83$ \\
\hline
\end{tabular}

SB: G. max; SF: H. annus; C: C. nucifera; SB:C: G. max: C. nucifera; SF:C: H. annus: C. nucifera. nd: not detected. Ole/Lin: oleic e linoleic. Averages \pm standard deviation of the analyses performed in triplicate followed by the same letter on the lines do not differ by Tukey test $(p>0,05)$.

The formation of secondary compounds of the oils was analyzed by the $\rho$-anisidine value, which, according to Guillén and Cabo (2002), an oil of good quality presents the maximum value of 10 . Initially the oils agreed with the maximum stipulated value. Among the SB, SF and C oils, during the period of thermoxidation, the $\mathrm{C}$ presented the lowest $\rho$ anisidine values, meanwhile, among the blends, the SF:C was the least oxidated.

Dias, Menis and Jorge (2015) in a accelerated storage test at $60{ }^{\circ} \mathrm{C} / 10$ days with $\mathrm{S} / \mathrm{V}$ of $0.3 / \mathrm{cm}$ obtained $\rho$-anisidine values under 4.3. On the other hand, $\mathrm{Yu}$, Cho and Hwang (2018) fried potato chips at $180{ }^{\circ} \mathrm{C}$ using refined $C$. nucifera oil and obtained in the times 0,2 , and $4 \mathrm{~h}$ the values of $1 ; 4.7$ and 7.3 .

In the beginning of the thermoxidation, in relation to Totox, the oils obtained values inside the limits stipulated by Berset and Cuvelier (1996) in which 10 means a good quality oil.
Initially, the $G$. max presented a value of 4.06 , the same as the one presented by Dias et al. (2015), who obtained 4.3. Meanwhile, the $H$. annus oil and the blends, SC and GC, presented the highest levels of oxidation.

With an increase of the oxidation time, it is possible to observe the Totox variation for the $\mathrm{C}$ and $\mathrm{SF}: \mathrm{C}$ oils due to their higher levels of peroxide. On the other side, the SB:C oil presented a linear increase of the value and could inhibit the formation of oxidation compounds in 5\% when compared to the G. max.

The thermoxidized oils were analyzed in relation to the conjugated dienoic acids and, initially, the G. $\max$ at zero time presented $0.34 \%$, a result similar to Silva and Jorge (2012) with $0.35 \%$. On the period of $0 \mathrm{~h}$ to $15 \mathrm{~h}$, the oils differed statistically, being the $\mathrm{C}$ and $\mathrm{GC}$ the ones which reached the lowest values. 
Table 3. Thermoxidation of the G. max, H. annus and $C$. nucifera oils and their blends during heating at $180^{\circ} \mathrm{C}$.

\begin{tabular}{|c|c|c|c|c|}
\hline \multirow{2}{*}{ Treat.- } & \multicolumn{4}{|c|}{ Heating times (hour) } \\
\hline & 0 & 5 & 10 & 15 \\
\hline \multicolumn{5}{|c|}{ Peroxide value (meq/kg) } \\
\hline SB & $1.04 \pm 0.01^{\mathrm{cB}}$ & $6.39 \pm 0.00^{\mathrm{bE}}$ & $6.53 \pm 0.01^{\mathrm{bD}}$ & $7.03 \pm 0.00^{\mathrm{aE}}$ \\
\hline SF & $1.40 \pm 0.00^{\mathrm{dA}}$ & $9.91 \pm 0.02^{\mathrm{cC}}$ & $10.51 \pm 0.01^{\mathrm{bC}}$ & $11.98 \pm 0.01^{\mathrm{aB}}$ \\
\hline $\mathrm{C}$ & $0.82 \pm 0.00^{\mathrm{dB}}$ & $37.05 \pm 0.51^{\mathrm{cA}}$ & $29.73 \pm 0.15^{\mathrm{bA}}$ & $39.00 \pm 0.00^{\mathrm{aA}}$ \\
\hline SB:C & $1.71 \pm 0.01^{\mathrm{dA}}$ & $8.64 \pm 0.01^{\mathrm{cD}}$ & $10.31 \pm 0.01^{\mathrm{aC}}$ & $9.31 \pm 0.01^{\mathrm{bC}}$ \\
\hline & $1.51 \pm 0.01^{\mathrm{dA}}$ & $12.61 \pm 0.01^{\mathrm{bB}}$ & $13.37 \pm 0.01^{\mathrm{aB}}$ & $7.72 \pm 0.01^{\mathrm{cD}}$ \\
\hline \multicolumn{5}{|c|}{$\rho$-anisidine value } \\
\hline SB & $1.98 \pm 0.00^{\mathrm{dA}}$ & $33.60 \pm 0.00^{\mathrm{cB}}$ & $34.35 \pm 0.00^{\mathrm{bA}}$ & $36.75 \pm 0.00^{\mathrm{aA}}$ \\
\hline SF & dA & $33.80 \pm 0.00^{\mathrm{cA}}$ & $34.27 \pm 0.01^{\mathrm{bB}}$ & $15 \pm 0.01^{\mathrm{aB}}$ \\
\hline $\mathrm{C}$ & $1.49 \pm 0$. & $9.88 \pm 0.00^{\mathrm{cE}}$ & $10.27 \pm 0.01^{\mathrm{bE}}$ & $14.28 \pm 0.01^{\mathrm{aE}}$ \\
\hline SB:C & $1.75 \pm 0$. & $20.01 \pm 0.01^{\mathrm{cC}}$ & $25.19 \pm 0$ & $29.36 \pm 0.01^{\mathrm{aC}}$ \\
\hline & $\mathrm{dC}$ & $17.59 \pm 0.01^{\mathrm{cD}}$ & $24.95 \pm 0$. & $\mathrm{aD}$ \\
\hline \multicolumn{5}{|c|}{ Totox: total oxidation value } \\
\hline SB & $4.06 \pm 0.16^{\mathrm{dB}}$ & & $47.41 \pm 0.0$ & $50.80 \pm 0.01^{\mathrm{aC}}$ \\
\hline SF & 4.7 & $53.62 \pm 0.08^{\mathrm{cB}}$ & $55.29 \pm 0$ & $58.41 \pm 0$ \\
\hline $\mathrm{C}$ & $3.13 \pm 0$. & $83.99 \pm 0.21^{\mathrm{bA}}$ & $69.72 \pm 0$ & $92.28 \pm 0$ \\
\hline & $5.17 \pm 0.01^{\mathrm{dA}}$ & $37.28 \pm 0.01^{\mathrm{cE}}$ & $45.82 \pm 0$ & $47.98 \pm 0.01^{\mathrm{aD}}$ \\
\hline & 4.6 & $42.80 \pm 0.00^{\mathrm{cD}}$ & $51.70 \pm 0.01^{\mathrm{aC}}$ & $44.70 \pm 0$ \\
\hline \multicolumn{5}{|c|}{ Conjugated dienoic acid (\%) } \\
\hline SB & dA & $0.89 \pm 0.01^{\mathrm{cA}}$ & $2.56 \pm 0.01^{\mathrm{bA}}$ & $3.00 \pm 0$ \\
\hline SF & $3 \pm 0$ & $0.78 \pm 0.0$ & $2.13 \pm 0$ & $2.51 \pm 0.00^{\mathrm{aB}}$ \\
\hline $\mathrm{C}$ & $0.14 \pm 0.0$ & $0.17 \pm 0.01^{\mathrm{bE}}$ & $0.18 \pm 0$. & $0.23 \pm 0.01^{\mathrm{aE}}$ \\
\hline & & $0.52 \pm 0$. & $2.21 \pm 0$ & $2.46 \pm 0$ \\
\hline & dD & $0.49 \pm 0.00^{\mathrm{cD}}$ & $1.76 \pm 0.0$ & $2.39 \pm 0$. \\
\hline \multicolumn{5}{|c|}{ Total polar compounds (\%) } \\
\hline $\mathrm{S}$ & $.67 \pm 0.06^{\mathrm{dA}}$ & & $35.20 \pm 0.0$ & $42.50 \pm 0.50^{\mathrm{aA}}$ \\
\hline $\mathrm{S}$ & $3.15^{ \pm} 0.05^{\mathrm{dB}}$ & $13^{\mathrm{cA}}$ & $32.15 \pm 0$. & $43.15 \pm 0.50^{\mathrm{aA}}$ \\
\hline $\mathrm{C}$ & $2.25 \pm 0.13^{\mathrm{dB}}$ & $13.25 \pm 0.13^{\mathrm{cB}}$ & $22.25^{ \pm} 0.50^{\mathrm{bC}}$ & $24.50 \pm 0.50^{\mathrm{aB}}$ \\
\hline & $2.35 \pm 0.25^{\mathrm{dB}}$ & $14.25 \pm 0.13^{\mathrm{cB}}$ & $22.50^{ \pm} 0.50^{\mathrm{bC}}$ & $24.50 \pm 0.50^{\mathrm{aB}}$ \\
\hline & $2.30 \pm 0.18^{\mathrm{dB}}$ & $14.15 \pm 0.05^{\mathrm{cB}}$ & $22.50 \pm 0.50^{\mathrm{bC}}$ & $25.50 \pm 0.50^{\mathrm{aB}}$ \\
\hline \multicolumn{5}{|c|}{ Oxidative stability index (hour) } \\
\hline SB & $\mathrm{aD}$ & & $1.06 \pm 0.20^{\mathrm{bB}}$ & $0.90 \pm 0.08^{\mathrm{bB}}$ \\
\hline SF & $5.80 \pm 0.01^{\mathrm{aD}}$ & $1.07 \pm 0.00^{\mathrm{bC}}$ & $0.50 \pm 0.05^{\mathrm{bBC}}$ & $0.66 \pm 0.01^{\mathrm{bBC}}$ \\
\hline $\mathrm{C}$ & $100.50 \pm 0.50^{\mathrm{aA}}$ & $71.01 \pm 0.01^{\mathrm{bA}}$ & $25.31 \pm 0.01^{\mathrm{cA}}$ & $25.35 \pm 0.01^{\mathrm{cA}}$ \\
\hline SB:C & $7.49 \pm 0.25^{\mathrm{aC}}$ & $3.16 \pm 0.01^{\mathrm{bB}}$ & $0.79 \pm 0.00^{\mathrm{cBC}}$ & $0.31 \pm 0.00^{\mathrm{cBC}}$ \\
\hline SF:C & $8.32 \pm 0.03^{\mathrm{aB}}$ & $0.55 \pm 0.01^{\mathrm{bC}}$ & $0.13 \pm 0.00^{\mathrm{bC}}$ & $0.15 \pm 0.03^{\mathrm{bC}}$ \\
\hline
\end{tabular}

SB: G. max; SF: H. annus; C: C. nucifera; SB:C: G. max: C. nucifera; SF:C: H. annus: $C$. nucifera. Averages \pm standard deviation of the analyses performed in triplicate followed by the same lowercases on the lines and uppercases on the columns do not differ by Tukey test $(\mathrm{p}>0,05)$.

Yu et al. (2018) fried potato chips in refined C. nucifera oil at $180{ }^{\circ} \mathrm{C}$ and obtained at times 0,2 and $4 \mathrm{~h}$ the values $4.5 ; 5.6$ and $6.8 \%$ respectively for conjugated dienoic acids. Differently, Jorge, Veronezi and Del Ré (2015) thermoxidatized the G. $\max$ oil at $180{ }^{\circ} \mathrm{C} / 15 \mathrm{~h}$ with $\mathrm{S} / \mathrm{V}$ of $0.4 / \mathrm{cm}$ and they obtained the results from 0.51 to $2.35 \%$ of conjugated dienoic acids.

According to Paul and Mittal (1997), good quality oils cannot exceed $25 \%$ of total polar compounds after processed in high temperatures. Observing Table 3, it is possible to see that initially the oils agreed with the stablished pattern, but as time passed at $10 \mathrm{~h}$ of heating, $\mathrm{S}$ and $\mathrm{G}$ could not be used anymore. However, the $\mathrm{C}, \mathrm{SB}: \mathrm{C}$ and $\mathrm{SF}: \mathrm{C}$ oils reached the maximum value of $24.5 \%$ and did not differ statistically at the end of the $15 \mathrm{~h}$ and did not need to be disposed.

Luzia and Jorge (2013) thermoxidized G. $\max$ oil at 180 ${ }^{\circ} \mathrm{C} / 15 \mathrm{~h}$ with $\mathrm{S} / \mathrm{V}$ of $0.4 / \mathrm{cm}$ and obtained $4.43 \%$ to $35.5 \%$, meanwhile Jorge, Veronezi and Pereira (2016) under the same conditions obtained from 4.12 to $23.52 \%$. Casarotti and Jorge
(2012) by the thermoxidation of the $G$. $\max$ oil at $180^{\circ} \mathrm{C} / 20$ $\mathrm{h}$ and $\mathrm{S} / \mathrm{V}$ of $0.4 / \mathrm{cm}$ obtained results from $1.38 \%$ to $33.16 \%$ of polar compounds.

Veronezi and Jorge (2018) formulated mixtures of $G$. max, C. papaya and C. melo oils in different proportions and subjected them to thermoxidation. The oil blends showed lower percentages of total polar compounds, greater oxidative stability, in addition to retaining tocopherols better than pure oils, in $20 \mathrm{~h}$ of heating.

The $C$. nucifera oil presented the highest oxidative stability during the period of thermoxidation. The major composition of this oil in saturated fatty acids made its stability more possible under high temperatures, providing it at the end of the $15 \mathrm{~h}$ approximately 24 more than the other oils. G. max and $H$. annus oils began with the lowest values of oxidative stability and at the end they reached the values of the SB:C and SF:C blends. The composition of natural antioxidants in the SB and SF oils allowed a better stability for these oils at the end of the $15 \mathrm{~h}$ compared to the $C$. nucifera when allowing stability to the SB:C and SF:C blends.

In a study carried out with mixtures of $L$. usitatissimum, $G$. hirsutum and $C$. nucifera oils under accelerated storage conditions, Pazzoti et al. (2018) observed that although the oils have degraded over time, it was possible to verify that $G$. hirsutum and $C$. nucifera oils contributed to increase the stability of the L. usitatissimum oil, which in turn increased the levels of bioactive compounds in C. nucifera oil.

\section{Conclusion}

The mostly saturated composition of the $C$. nucifera oil contributed for the formation of the oil blends with balanced fatty acids profile. The SF:C oil reached approximately the desired composition of 1:1:1 in saturated, monounsaturated and polyunsaturated fatty acids. The thermoxidation proved the efficiency of the oil blends with the lowest values of oxidation and highest oxidative stability. Therefore, the SB:C and SF:C oils can be used as substitutes of the SB and $\mathrm{SF}$ oils in processes that require high temperatures, as they provide greater oxidative stability and nutritional quality.

\section{References}

AOCS Official and tentative methods of the American Oil Chemists' Society (2009), American Oil Chemists' Society Press ( $6^{\text {th }}$ Ed.), Champaign

Berset, C., \& Cuvelier, M.E. (1996). Methods of estimating the degree of lipid oxidation and of measuring antioxidizing power. Sciences des Aliments, 16(3), 219-245.

Boukandoul, S., Santos, C.S.P., Casal, S., \& Zaidia, F. (2019). Oxidation delay of sunflower oil under frying by moringa oil addition: more than just a blend. Journal of the Science of Food and Agriculture, 99, 54835490. doi:10.1002/jsfa.9809.

Casarotti, S.N., \& Jorge, N. (2012). Antioxidant activity of Rosemary extract in soybean oil under thermoxidation. Journal of Food Processing and Preservation, 38(1), 136-145. doi: 10.1111/j.17454549.2012.00755.x

Codex Alimentarius. (2009). International Food Standards. Codex-Stan 210: Standard for named vegetable oils, Rome.

Dayrit, F.M. (2015). The properties of lauric acid and their significance in coconut oil. Journal of the American Oil Chemists' Society, 92(1), 115. doi: 10.1007/s11746-014-2562-7.

Dias, L.S., Menis, M.E.C., \& Jorge, N. (2015). Effect of Rosemary (Rosamarinus officinalis) extracts on the oxidative stability and sensory 
acceptability of soybean oil. Journal of the Science of Food and Agriculture, 95(10), 2021-2027. doi 10.1002/jsfa.6914.

Dobarganes, M.C., Velasco, J., \& Dieffenbacher A. (2000). Determination of polar compounds, polymerized and oxidized triacylglycerols, and diacylglycerols in oils and fats. Pure and Applied Chemistry, 72(8), 15631575. doi: 10.1351/pac200072081563.

Farhoosh, R., Einafshar, S., \& Sharayei, P. (2009). The effect of commercial refining steps on the rancidity measures of soybean and canola oils. Food Chemistry, 115(3), 933-938. doi: 10.1016/j.foodchem.2009.01.035.

Guillén, M.D., \& Cabo, N. (2002). Fourier transform infrared spectra data versus peroxide and anisidine values to determine oxidative stability of edible oils. Food Chemistry, 77(4), 503-510. doi: 10.1016/S03088146(01)00371-5

Gunstone, F.D. (2011). Vegetable oils in food technology: composition, properties and uses. $2^{\text {nd }}$ ed. Oxford: Wiley-Blackwell.

Hartman, L., \& Lago, R. (1973). Rapid preparation of fatty acid methyl esters from lipids. Laboratory Practice, 22(6), 475-476.

Huimin, X., Lin, L., Shilin, G., Elfalleh, W., He, S., Qinghai, S., \& Ying, M. (2014). Formation, stability, and properties of an algae oil emulsion for application in UHT milk. Food and Bioprocess Technology, 7(2), 567574. doi: 10.1007/s11947-013-1054-3.

ICMR. (1989). Indian Council for Medical Research. Nutrient requirements and recommended daily allowances for Indians, New Delhi.

Jorge, N., Veronezi, C.M., \& Del Ré, P.V. (2015). Antioxidant effect of thyme (Thymus vulgaris L.) and oregano (Origanum vulgare L.) extracts in soybean oil under termoxidation. Journal of Food Processing and Preservation, 39(6), 1399-1406. doi: 10.1111/jfpp.12358.

Jorge, N., Veronezi, C.M., \& Pereira, D.C. (2016). Extracts of red peppers: antioxidant activity and sensory evaluation. Nutrition \& Food Science, 46(2), 228-236. doi: 10.1108/NFS-08-2015-0094.

Khan, M.I., Asha, M.R., Bhat, K.K., \& Khatoon, S. (2011). Studies on chemical and sensory parameters of coconut oil and its olein blends with sesame oil and palmolein during wheat flour-based product frying. Journal of Food Science and Technology, 48(2), 175-182. doi: 10.1007/s13197-010-0145-7.

LaRosa, J.C., Hunninghake, D., Bush, D., Criqui, M.H., Getz, G.S., Gotto Jr, A.M., Grundy, S.M., Rakita, L., Robertson, R.M., \& Weisfeldt, M.L. (1990). The cholesterol facts. A summary of the evidence relating dietary fats, serum cholesterol, and coronary heart disease. A joint statement by the American Heart Association and the National Heart, Lung, and Blood Institute. The Task Force on Cholesterol Issues, American Heart Association. Circulation, 81(5), 1721-1733. doi: 10.1161/01.cir.81.5.1721.

Luzia, D.M.M., \& Jorge, N. (2013). Fatty acids profile and alteration of lemon seeds extracts (Citrus limon) added to soybean oil under thermoxidation. Journal of Food Science and Technology, 50(5), 965-971. doi: 10.1007/s13197-011-0411-3

Mahan, I.K., \& Escott-Stump, S.K. (2010). Alimentos, nutrição e dietoterapia. São Paulo, Brasil: Roca

Marina, A.M., Che-Man, Y.B., Nazimah, S.A.H., \& Amin, I. (2009). Chemical properties of virgin coconut oil. Journal of the American Oil Chemists' Society, 86(4), 301-307. doi: 10.1007/s11746-009-1351-1.

Miles, E.A., \& Calder, P.C. (2012). Influence of marine n-3 polyunsaturated fatty acids on immune function and a systematic review of their effects on clinical out comes in rheumatoid arthritis. British Journal of Nutrition, 107, S171-S184. doi: 10.1017/S0007114512001560.

Nyam, K.L., Tan, C.P., Lai, O.M., Long, K., \& Che Man, Y.B. (2009). Physicochemical properties and bioactive compounds of selected seed oils. LWT - Food Science and Technology, 42(8), 1396-1403. doi: 10.1016/j.1wt.2009.03.006.

Patil, U., \& Benjakul, S. (2018). Coconut milk and coconut oil: their manufacture associated with protein functionality. Journal of Food Science, 83(8), 2019-2027. doi: 10.1111/1750-3841.14223.

Patil, U., \& Benjakul, S. (2019). Use of protease from seabass pyloric caeca in combination with repeated freeze-thawing cycles increases the production efficiency of virgin coconut oil. European Journal of Lipid Science and Technology, 121(5), 1800460. doi: 10.1002/ejlt.201800460.

Paul, S., \& Mittal, G.S. (1997). Regulating the use of degraded oil/fat in deepfat/oil food frying. Critical Reviews in Food Science and Nutrition, 37(7), 635-662. doi: 10.1080/10408399709527793.
Pazzoti, G., Souza, C., Veronezi, C., Luzia, D., \& Jorge, N. (2018). Evaluation of oxidative stability of compound oils under accelerated storage conditions. Brazilian Archives of Biology and Technology, 61: e18180055. doi: 10.1590/1678-4324-2018180055.

Ribeiro, L.G.T. (2017). The scientific truth about a super functional food denominated coconut oil. Brazilian Journal of Surgery and Clinical Research, 18(3), 109-117. Recovered from: https://www.mastereditora.com.br/periodico/20170519_071843.pdf

Santos, C., \& Weaver, D.F. (2018). Topically applied linoleic/linolenic acid for chronic migraine. Journal of Clinical Neuroscience, 58, 200-201. doi: 10.1016/j.jocn.2018.10.013

Savva, S.C., \& Kafatos, A. (2016). Vegetable oils: dietary importance. In G. Smithers (Ed.), Reference module in food science. Amsterdam: Elsevier.

Sawada, N., Inoue, M., Iwasaki, M., Sasazuki, S., Shimazu, T., Yamaji, T., Takachi, R., Tanaka, Y., Mizokami, M., \& Tsugane, S. (2012). Consumption of n-3 fatty acids and fish reduce risk of hepatocellular carcinoma: Japan public health centerbased prospective study. Gastroenterology, 142(7), 1468-1475. doi: 10.1053/j.gastro.2012.02.018.

Silva, A.C., \& Jorge, N. (2012). Oxidative stability of soybean oil added to Lentinys edodes and Agaricus blazei mushrooms extracts in an accelerated storage test. Nutrition \& Food Science, 42(1), 34-40. doi: $10.1108 / 00346651211196519$

Silva, F.A.M., Borges, M.F., \& Ferreira, M.A. (1999). Métodos para avaliação do grau de oxidação lipídica e da capacidade antioxidante. Química Nova, 22(1), 94-103.

Toscano, G., Riva, G., Foppa-Pedretti, E., \& Duca, D. (2012). Vegetable oil and fat viscositu forecast models based on iodine number and saponification number. Biomass and Bioenergy, 46, 511-516. doi: 10.1016/j.biombioe.2012.07.009

Veronezi, C.M., \& Jorge, N. (2018). Effect of Carica papaya and Cucumis melo seed oils on the soybean oil stability. Food Science and Biotechnology, 22(4), 1031-1040. doi: 10.1007/s10068-018-0325-1.

Weng, X.C., \& Wang, W. (2000). Antioxidant activity of compounds isolated from Salvia plebeia. Food Chemistry, 71(4), 489-493. doi: 10.3923/pjn.2011.694.701.

Yu, K.S., Cho, H., \& Hwang, K.T. (2018). Physicochemical properties and oxidative stability of frying oils during repeated frying of potato chips. Food Science and Biotechnology, 27(3), 651-659. doi: 10.1007/s10068017-0292-y.

License: Creative Commons CC BY 4.0

This article was published with open access for distribution under the terms of the Creative Commons Attribution License, which allows unrestricted use, distribution, and reproduction in any medium, provided the original work is properly cited. 